\title{
Efficient regeneration protocol for callus and shoot induction from recalcitrant Phaseolus vulgaris L. explants under optimum growth conditions
}

\author{
Alfred Besra \& Jolly Basak \\ Genomics of Plant Stress Biology Laboratory, Department of Biotechnology, Visva-Bharati, Santiniketan 731 235, India \\ *Email: jolly.basak@visva-bharati.ac.in
}

\section{ARTICLE HISTORY}

Received: 12 April 2021

Accepted: 08 June 2021

Available online: 19 August 2021

\section{KEYWORDS}

Auxin

Callus induction

Cytokinin

Phaseolus vulgaris

Shoot regeneration
ABSTRACT

Callus is the most significant morphogenic response obtained in plant tissue culture studies. It can be used for micropropagation or to create transgenic lines. Phaseolus vulgaris L. (common bean) is one of the economically important crops with a great nutritional value. However, very little effort has been made to regenerate callus from $P$. vulgaris explants. Six explants were used namely root tip, leaves, plumule, radicle, cotyledon and embryo to develop a callus from $P$. vulgaris. The minimum days for callus induction was 10 days in plumule, radicle and embryo explants, while the maximum was 15 days in cotyledon explants with the callus induction percentage of $75 \%$. The largest callus was found to be $2.77 \mathrm{gm}$ in weight and $2.5 \mathrm{~cm}$ in diameter in MS medium. Medium with different concentrations of plant growth regulators (PGRs) showed different growth pattern in callus induction. Culture medium with $1.50 \mathrm{mg} / \mathrm{l}$ of BAP, $0.50 \mathrm{mg} / \mathrm{l}$ of $2,4-\mathrm{D}$ and $0.10 \mathrm{mg} / \mathrm{l}$ of NAA showed the best result in callus induction. Higher concentration of BAP $(2.00 \mathrm{mg} / \mathrm{l})$, along with $0.25 \mathrm{mg} / \mathrm{l}$ of 2, 4-D was ideal for shoot regeneration and maturation. Shoot induction medium along with $2.00 \mathrm{mg} / \mathrm{I}$ of NAA concentrations were found to be best for rooting. It was found that plumule and radicle favor callus induction, however, they are also potent for shoot and root induction. Knowledge gained in this study will be useful in developing a standard protocol for plant regeneration from $P$. vulgaris explants and will also be useful in creating transgenic line of $P$. vulgaris.

\section{Introduction}

Plant tissue culture is a method of aseptic culture of cells or tissues or any part of the plant in the growth medium, under the optimum condition with nutritional supplements (1). The optimum conditions provide an environment including adequate temperature, suitable $\mathrm{pH}$ medium and proper gaseous environment $\left(\mathrm{CO}_{2}\right.$ concentration), which allow explants to multiply. The nutritional medium consists of carbon source, phytohormones and natural extracts, which are also important for explant growth and development (2). Phaseolus vulgaris L. is a vital leguminous crop in tropical and subtropical areas of Asia, Africa and Latin America, as well as parts of southern Europe (3). However, very less effort has been made to develop callus from different parts of common bean, using plant tissue culture methods. Callus induction followed by successive plant regeneration is the fastest way of getting healthy plantlets, without relying on the seasons. Common bean callus induction and regeneration is very effective for mass propagation and for genetic manipulation in $P$. vulgaris.

There are different mechanisms that induce callus formation from different explants. Pathways that are induced by auxin are called auxin-induced callus formation pathway. Such pathways are controlled by DNA binding auxin response factors (ARFs). ARFs target gene as a transcriptional factor and activates the gene which is responsible for auxin response to initiate callus formation (4). AFRs binds to auxin response DNA elements (AuxRE) at the site of the promoter region of auxin-regulated gene and acts as a repressor or activator of these genes. Similarly, the lateral organ boundary domain (LBD) also contributes to callus induction in plant species $(5,6)$. Cytokinin induced callus formation is triggered by cyclin-dependent kinase (CYCD) which is involved in plant morphogenesis by controlling cell proliferation and differentiation in the plant. Along with ARFs and CYCD, another factor that induces callus formation is wound-induced dedifferentiation factor (WIND). Studies revealed that wounding in any part of the

(c) Besra \& Basak (2021). This is an open-access article distributed under the terms of the Creative Commons Attribution License, which permits unrestricted use, distribution and reproduction in any medium, provided the original author and source are credited (https://creativecommons.org/licenses/by/4.0/) 
plant also causes callusing, which is facilitated by WIND gene expression (6).

In previous studies, different concentrations of cytokinin to auxin ratio or the combination of other micro and macro elements, vitamins is considered ideal for callus induction $(7,8)$. Interestingly, it has been hypothesized that equal combination of cytokinin to auxin ratio is ideal for callus induction, but in practice cytokinin to auxin concentration varies in a wide range, depending upon the plant species. This may be due to various endogenous response of explant against the hormonal concentration of plant growth regulators (PGRs) (9). Commonly used cytokinin is 6-Benzylaminopurine (6BAP) which is potent for callogenesis alone or combination with other PGRs and supplements (10). In the case of auxin, 2,4-Dichlorophenoxyacetic acid (2,4-D) and 1-Naphthaleneacetic acid (NAA) is essential for callus induction (9). All these combinations lead to a significant amount of callus induction and multiple shoots and root induction in plants. The higher concentration of 2,4-D and NAA helps in callus differentiation and more effective in shoot and root regeneration (11).

Callusing can be done by taking explants from different parts of the plant like stem, root, node, shoot, embryo, full cotyledon, half cotyledon, leaf etc (12). Development of callus in $P$. vulgaris is difficult, due to its recalcitrant nature $(13,14)$. Therefore, the selection of explant in $P$. vulgaris is vital to develop callus followed by shooting and rooting.

The present study aimed to gain information about which part of the plant is more potent to be taken as explant for callus induction and its response to the different combinations of PGRs (6-BAP, 2,4-D and NAA for callusing). Therefore, the thrust of the present study is to determine an effective procedure for callus induction and rapid plant regeneration from explants taken from $P$. vulgaris.

\section{Materials and Methods}

\section{Explant selection}

Different parts of the plant have differential ability to induce into a callus and can be considered as explants (15). In general, explants can be taken from any part of the plant. For this study different explants form $P$. vulgaris L. (selection 9 variety, India) including root tip, leaf, embryo, plumule, radical and cotyledon were taken for callus induction and plant regeneration (Fig. 1).

\section{Dissection and surface sterilization}

The seeds of $P$. Vulgaris were kept in autoclaved distilled water in a petriplate for 4-6 hr so that they become soft to be dissected aseptically under laminar airflow. Before dissection, all the explants were subjected to surface sterilization. For sterilization explants were treated with $70 \%$ ethanol for 30 seconds followed by washing 3 to 4-times with autoclaved distilled water. The explants were then soaked for $5-10 \mathrm{~min}$ in $0.1 \%$ fungicide (carbendazim) and for $1 \mathrm{~min}$ in $3 \% \mathrm{NaOCl}$ (Sodium hypochlorite) followed by washing with distilled water (12).

\section{Plant growth regulators}

Murashige and Skoog (MS media) (16) has been used

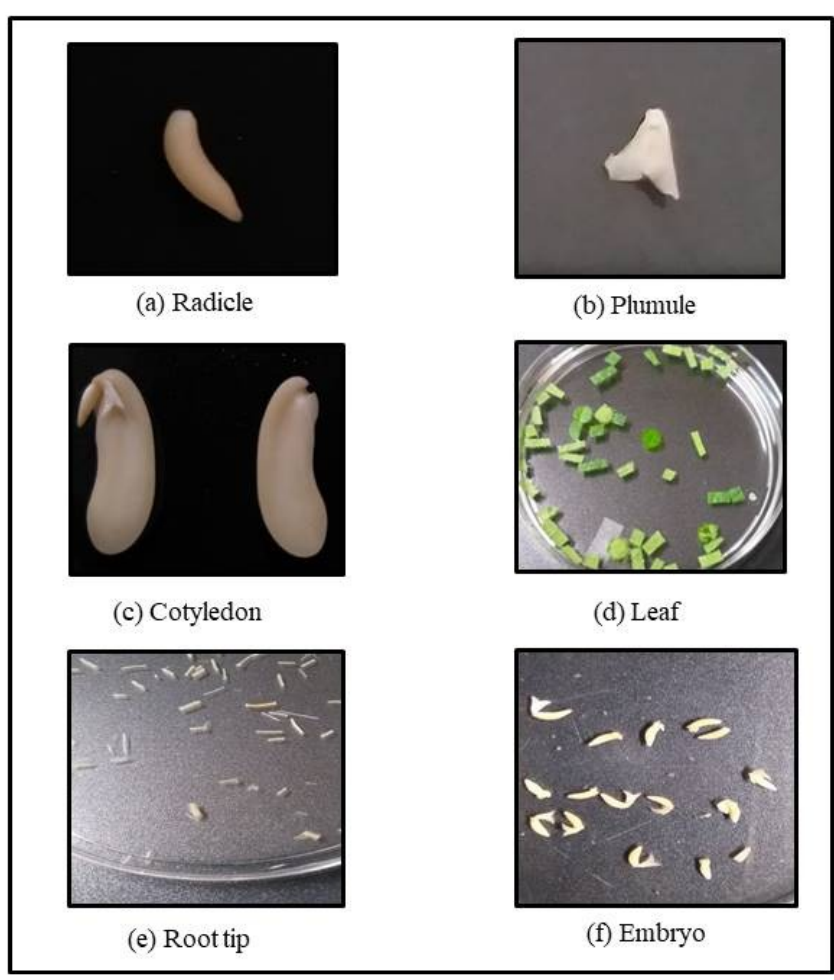

Fig. 1. Selection of explant transfer to MS medium for callus induction (Magnification 1x).

as media for all the tissue culture experiments, with $0.04 \% \mathrm{CaCl}_{2}, 0.003 \%$ FeNaEDTA, vitamins, 3\% sucrose, $0.8 \%$ agar. The $\mathrm{pH}$ of media was adjusted to $5.7 \pm 0.1$ using $1 \mathrm{M} \mathrm{HCl}$ or $1 \mathrm{M} \mathrm{NaOH}$ before adding the agar. In the MS media four different concentration of BAP, 2,4-D and NAA is used for callus induction and described below:

\section{For callus induction:}

$2.00 \mathrm{mg} / \mathrm{l} \mathrm{BAP}+1.00 \mathrm{mg} / \mathrm{l}$ 2,4-D+0.20 mg/l NAA,

$1.50 \mathrm{mg} / \mathrm{l} \mathrm{BAP}+0.50 \mathrm{mg} / \mathrm{l}$ 2,4-D+0.10 mg/l NAA,

$1.00 \mathrm{mg} / \mathrm{l} \mathrm{BAP}+0.25 \mathrm{mg} / \mathrm{l}$ 2,4-D+0.05 mg/l NAA,

$0.50 \mathrm{mg} / \mathrm{l} \mathrm{BAP}+0.125 \mathrm{mg} / \mathrm{l}$ 2,4-D, $0.025 \mathrm{mg} / \mathrm{l} \mathrm{NAA}$.

For shoot and root regeneration:

$2.00 \mathrm{mg} / \mathrm{l} \mathrm{BAP}+0.25 \mathrm{mg} / \mathrm{l} 2,4-\mathrm{D}$,

$2.00 \mathrm{mg} / \mathrm{l} \mathrm{BAP}+0.25 \mathrm{mg} / \mathrm{l} 2,4-\mathrm{D}+2.00 \mathrm{mg} / \mathrm{l} \mathrm{NAA}$,

$2.00 \mathrm{mg} / \mathrm{l} \mathrm{BAP}+2.00 \mathrm{mg} / \mathrm{l} \mathrm{NAA}$,

$2.00 \mathrm{mg} / \mathrm{l}$ 2,4-D and $2.00 \mathrm{mg} / \mathrm{l} \mathrm{NAA}$.

\section{Inoculation}

All the explants were dissected aseptically into 3-5 $\mathrm{mm}$ size and transferred to MS media supplemented with different concentrations of PGRs. These explants were kept in incubation in the plant growth chamber for callus induction at $25 \pm 2{ }^{\circ} \mathrm{C}$ for one week in dark, followed by $16 \mathrm{hr}$ light/8 hr dark photoperiod of 45 $\mu \mathrm{mol} \mathrm{m}^{-2} \mathrm{~s}^{-1}$ for 15 days. Once the callus induction started and reached to certain masses, it was chopped into small fragments and transferred into the secondary medium (callus proliferation media) and kept there for 30 days to get more number of callus. The mature calluses were then transferred into the shoot induction medium for shoot regeneration at $23 \pm 2{ }^{\circ} \mathrm{C}$. The regenerated shoots were 
then transferred into the root induction media with PGRs promoting rooting.

\section{Parameters Measured}

Observed parameters for callus induction were weight of callus, diameter of callus, texture of callus and colour of the callus, callus induction percentage. All these data were recorded after 6-7 weeks. The observed parameters for shoot induction were number of shoots, length of shoots $(\mathrm{cm})$ and number of leafs. Callus induction percentage have been measured using the following formula:

Percentage of callus induction $=$ Number of explants with calluses / Total number of explants $\times 100$.

\section{Microscopic analysis}

Fifteen days old calluses were taken for the histological and microscopic analysis. These calluses were carefully chopped into small fragments (3-4 $\mathrm{mm}$ ), stained with $0.1 \%$ safranin and air-dried for 5 min and then were fixed into grease-free slides. The prepared slides were then subjected to microscopic study.

\section{Statistical analysis}

For statistical analysis, 4 explants were used from $P$. vulgaris, each from embryo, plumule, radical and cotyledon. Four replicates from each explant were taken with 4 combinations of different PGR concentrations. All the observed data were carefully analyzed using one way anova in Microsoft excel 2010 with $\mathrm{p}<0.05$ for statistical significance.

\section{Results}

\section{Effect of PGRs on callogenesis}

All the 6 explants namely root tip, leaf, embryo, plumule, radical and cotyledon were capable of developing into callus, and were transferred to the MS medium with different PGRs concentrations (Fig. 1). Out of the 6 explants, embryo, plumule, radicle and cotyledon showed positive result for callus induction, whereas, leaf and root tip explants didn't responded to any hormonal concentration and remain unchanged in the given medium. The effect of PGRs on callogenesis on different explants is presented in Table 1 . Of the 6 explants, plumule and radicle showed the best response. There are wide range of differences in the weight of the callus, colour of the callus, texture and diameter. This may be due to the variation in the concentration of auxin to cytokinin ratio and type of the explants used (embryo, cotyledon, radicle and plumule). Steps involved in callus induction and plant regeneration from explants is represented in supplementary Fig. S1.

\section{Microscopic study}

This study revealed that most of the callus obtained from plumule and radicle were of fibrous nature due to loose structure and arrangement of thin-walled parenchyma cells, emerging from the proliferating cells of the explant (Fig. 2). Callus obtained from cotyledon and embryo, on the other hand, had a more rigid and compact structure compare to plumule and radicle. In case of callus from plumule and radicle, when kept under incubation for more than thirty days, root and shoot induction started.

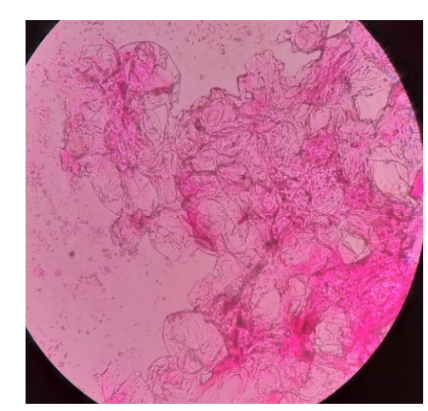

(a) (b)

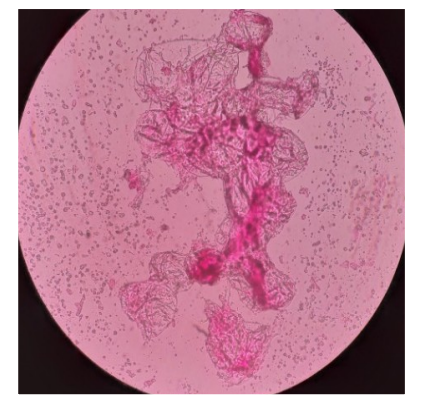

Fig. 2. Histological study of callus obtained from radicle explant, developed from $1.50 \mathrm{mg} / \mathrm{l}$ of BAP, $0.50 \mathrm{mg} / \mathrm{l}$ of 2 , 4 -D and $0.10 \mathrm{mg} / \mathrm{l}$ of NAA. Figure (a) and (b) are from two different calluses showing isodiametric and cytoplasmically dense cell (Magnification 40x).

\section{Callus induction}

All data from the experiments were carefully taken after 6 or 7 weeks of culture. The cause of these variations arises due to the differential interaction or response of the explants to the different concentrations of auxin and cytokinin given in the medium. The initiation of callus from explant varies in a number of days. The explants radical and plumule were more responsive to the hormonal concentration compared to the embryo and cotyledon (Table 1). The effect of cytokinin on callogenesis resulted in a decrease in the lignification of the cell wall, thereby promoting callus induction and growth. The growth pattern indicates that, the callus initiation starts from the cut region on the explant and later covers the entire part of the explant with time. Initially, the calluses were colourless, after a few weeks they become yellowish and later become light green in colour. Different explants also showed variation in appearances of colour. Radicle and plumule were found to be more responsive in colour appearance, initially colourless then yellowish and finally light green. Cotyledon and embryo were slow to respond and took more time for color appearance. Callus originating from plumule and radicle were more fibrous in nature and very easy to break into small fragments, ideal for callus multiplication. When these calluses were kept for a longer time under incubation, shoot induction started and some become brownish, due to oxidation of phenolic compounds. Previous studies on callus indicate that green and yellowish calluses are more efficient and have good regeneration ability and compact structure, hence promote shoot regeneration and proliferation (17).

\section{Effect of PGRs on callus induction}

Explants showed wide range of variations against PGRs. Explants with no PGRs didn't show any changes at all (Table 1). Days for callus induction varied from 10-30 days, having weight ranging from $0.54 \mathrm{gm}-2.77 \mathrm{gm}$ and diameter $0.7 \mathrm{~cm}-2.5 \mathrm{~cm}$, respectively. The maximum callus induction percentage is $75 \%$ (plumule and radicle). MS medium supplemented with $1.50 \mathrm{mg} / \mathrm{l}$ of BAP, $0.50 \mathrm{mg} / \mathrm{l}$ of 2, 4- 
Table 1. Qualitative study of callus induced from explants; (a) embryo; (b) cotyledon; (c) plumule; (d) radicle. Note: No Callus (-); Small Callus (+); Medium Callus(++); Large Callus (+++); Extra-large Callus (++++)

\begin{tabular}{|c|c|c|c|c|c|c|c|}
\hline explant & \multicolumn{3}{|c|}{ PGRs (mg/l) } & \multicolumn{4}{|c|}{ Callus induction parameters } \\
\hline \multirow{6}{*}{ Plumule } & BAP & $2,4 \mathrm{D}$ & NAA & $\begin{array}{l}\text { Degree of } \\
\text { callus } \\
\text { formation }\end{array}$ & $\begin{array}{c}\text { Callus induction } \\
\%\end{array}$ & Texture of callus & Colour of callus \\
\hline & \multicolumn{3}{|c|}{ MS Medium (control) } & - & 0.0 & - & - \\
\hline & 2.00 & 1.00 & 0.20 & - & 0.0 & - & - \\
\hline & 1.50 & 0.50 & 0.10 & ++ & 75.00 & Fibrous & Yellowish \\
\hline & 1.00 & 0.25 & 0.05 & + & 56.25 & hard & Dark Brown \\
\hline & 0.50 & 0.125 & 0.025 & ++++ & 50.00 & Compact & Brownish \\
\hline
\end{tabular}

(a)

\begin{tabular}{|c|c|c|c|c|c|c|c|}
\hline explant & \multicolumn{3}{|c|}{ PGRs (mg/l) } & \multicolumn{4}{|c|}{ Callus induction parameters } \\
\hline \multirow{6}{*}{ Radicle } & BAP & $2,4 \mathrm{D}$ & NAA & $\begin{array}{c}\text { Degree of } \\
\text { callus } \\
\text { formation }\end{array}$ & $\begin{array}{c}\text { Callus } \\
\text { induction \% }\end{array}$ & $\begin{array}{l}\text { Texture of } \\
\text { callus }\end{array}$ & Colour of callus \\
\hline & \multicolumn{3}{|c|}{ MS Medium (control) } & - & 0.00 & - & - \\
\hline & 2.00 & 1.00 & 0.20 & - & 0.00 & - & - \\
\hline & 1.50 & 0.50 & 0.10 & ++ & 75.00 & Fibrous & Yellowish \\
\hline & 1.00 & 0.25 & 0.05 & + & 54.16 & hard & Dark Brown \\
\hline & 0.50 & 0.125 & 0.025 & ++++ & 47.91 & Compact & Brownish \\
\hline
\end{tabular}

(b)

\begin{tabular}{cccccccc}
\hline explant & \multicolumn{3}{c}{ PGRs (mg/l) } & \multicolumn{3}{c}{ Callus induction parameters } \\
\hline \multirow{5}{*}{ embryo } & BAP & $\mathbf{2 , 4} \mathbf{D}$ & NAA & $\begin{array}{c}\text { Degree of } \\
\text { callus } \\
\text { formation }\end{array}$ & $\begin{array}{c}\text { Callus } \\
\text { induction \% }\end{array}$ & Texture of callus & Colour of callus \\
\cline { 2 - 8 } & \multicolumn{2}{c}{ MS Medium (control) } & - & 0.00 & - & - \\
\cline { 2 - 8 } & 2.00 & 1.00 & 0.20 & - & 0.00 & Hard & Dark Brown \\
\cline { 2 - 8 } & 1.50 & 0.50 & 0.10 & ++ & 45.83 & Compact & Brownish \\
\hline
\end{tabular}

(c)

\begin{tabular}{|c|c|c|c|c|c|c|c|}
\hline explant & \multicolumn{3}{|c|}{ PGRs (mg/l) } & \multicolumn{4}{|c|}{ Callus induction parameters } \\
\hline \multirow{6}{*}{ cotyledon } & BAP & $2,4 \mathrm{D}$ & NAA & $\begin{array}{l}\text { Degree of } \\
\text { callus } \\
\text { formation }\end{array}$ & $\begin{array}{c}\text { Callus } \\
\text { induction \% }\end{array}$ & $\begin{array}{l}\text { Texture of } \\
\text { callus }\end{array}$ & Colour of callus \\
\hline & \multicolumn{3}{|c|}{ MS Medium (control) } & - & 0.00 & - & - \\
\hline & 2.00 & 1.00 & 0.20 & - & 0.00 & - & - \\
\hline & 1.50 & 0.50 & 0.10 & ++ & 31.25 & Hard & Dark Brown \\
\hline & 1.00 & 0.25 & 0.05 & ++++ & 29.16 & Hard & Dark Brown \\
\hline & 0.50 & 0.125 & 0.025 & + & 18.75 & Compact & Brownish \\
\hline
\end{tabular}

(d)

D and $0.10 \mathrm{mg} / \mathrm{l}$ of NAA is found to be the best for callusing with minimum (10 days) and maximum (15 days). PGRs combinations having $1.00 \mathrm{mg} / \mathrm{l}$ of $\mathrm{BAP}+0.25 \mathrm{mg} / \mathrm{l}$ of $2,4-\mathrm{D}+0.05 \mathrm{mg} / \mathrm{l}$ of $\mathrm{NAA}$ and 0.50 $\mathrm{mg} / \mathrm{l}$ of BAP+0.125 mg/l of 2, 4-D+0.025 mg/l of NAA also showed positive result for callus induction. However, these calluses were hard, compact and nonresponsive to shoot regeneration, so these two PGRs combination were not used for further experiments. Higher concentrations PGRs combination with 2.00 $\mathrm{mg} / \mathrm{l}$ of BAP, $1 \mathrm{mg} / \mathrm{l}$ of 2,4-D and $0.20 \mathrm{mg} / \mathrm{l}$ of NAA didn't show any effect in all the explants for callus induction and led to organogenesis. In plumule and radicle explants, lower concentration of PGRs combination with $0.50 \mathrm{mg} / \mathrm{l}$ of BAP, $0.125 \mathrm{mg} / \mathrm{l}$ of 2,4$\mathrm{D}$ and $0.25 \mathrm{mg} / \mathrm{l}$ of NAA gave rise to extra-large callus formation. On the other hand, embryo explant with $1.50 \mathrm{mg} / \mathrm{l}$ of BAP, $0.50 \mathrm{mg} / \mathrm{l}$ of 2,4-D and $0.10 \mathrm{mg} / \mathrm{l}$ of NAA gave medium size calluses. In cotyledon explant, PGRs with $1 \mathrm{mg} / \mathrm{l}$ of BAP, $0.25 \mathrm{mg} / \mathrm{l}$ of 2,4-D and 0.05 $\mathrm{mg} / \mathrm{l}$ of NAA induced large callus formation.

\section{Differential response of explant on callus induction}

Out of the 4 types of explants taken from P. vulgaris, plumule (10 days) and radicle (10 days) (Fig. 4, 5) showed the best response compare to cotyledon (15 days) and embryo (10 days) in terms of days for callus induction. Plumule and radicle also showed higher weight $(1.3 \mathrm{gm})$ and bigger callus $(2.2-2.3 \mathrm{~cm})$ compared to embryo (Fig. 4, 5). In case of cotyledon, the weight $(2.3 \mathrm{gm})$ and diameter $(2.5 \mathrm{~cm})$ were greater in size but not regenerative due to the release of phenolic compounds leading to necrosis (Fig. 3). The result explains that plumule and radicle has a greater ability to respond to the combination of auxin and cytokinin. Though, $P$. vulgaris is recalcitrant in nature, still it is possible to get callus from plumule and radicle explant of $P$. vulgaris. This result explained that in $P$. vulgaris plumule and radicle can be used for callus induction and found to be best for callus induction and multiplication. For the later experiments, callus induced from plumule and 


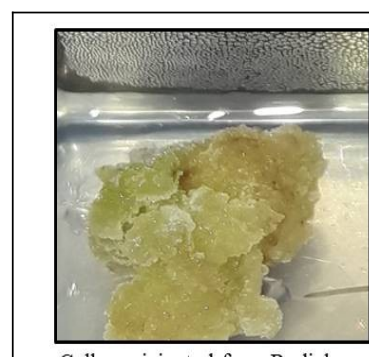

Callus originated from Radicle

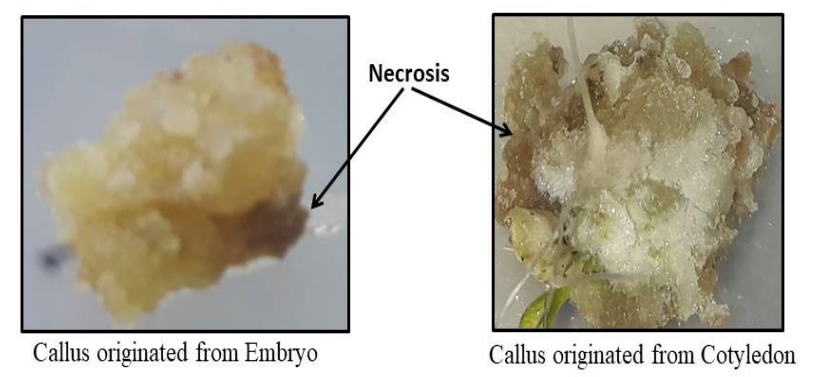

Fig. 3. Callus morphology: Callus induction from four different explants, after 15 days (Radicle, Plumule, Embryo, Cotyledon) (Magnification 1x).

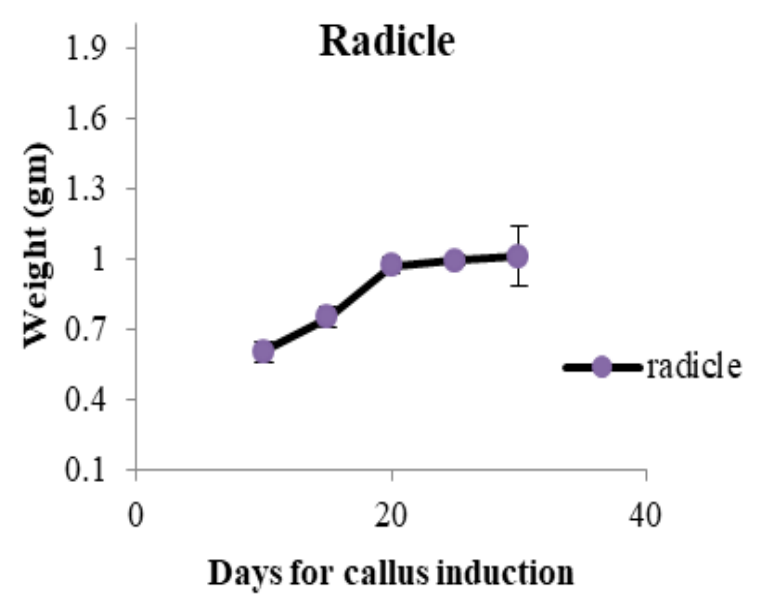

(a)

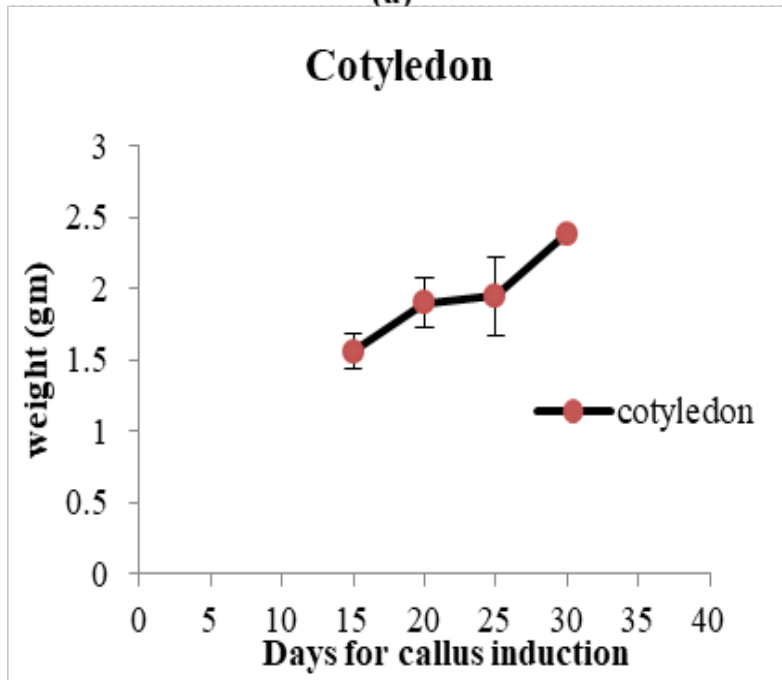

(c) radicle were selected and subcultured for the shoot and root induction.

\section{Effect of PGRs on shoot regeneration from calli}

Calluses developed from explant plumule and radicle were subculture into shoot induction medium (SIM), having a different combination of BAP, NAA and 2, 4$\mathrm{D}$ for shoot regeneration. MS medium supplemented with auxin and cytokinin helps to reduce the time of shoot regeneration and gives rise to multiple shoot induction. Yellowish callus was used for shoot regeneration, because of its ability to regenerate shoot. In this case, the shoot regeneration started between 20 to 30 days (Fig. 6).

During this period, the shoot induction medium was routinely changed every week, and the shoot regeneration parameters were measured. The result revealed that BAP and 2, 4-D together gives rise to multiple shoot induction with multiple leaves (Fig. 7) and found to be more effective without NAA. The best combination was $2.00 \mathrm{mg} / \mathrm{l}$ of BAP and $0.25 \mathrm{mg} / \mathrm{l}$ of 2 , 4-D followed by (i) $2.00 \mathrm{mg} / \mathrm{l}$ of BAP, $0.25 \mathrm{mg} / \mathrm{l}$ of 2, 4-D

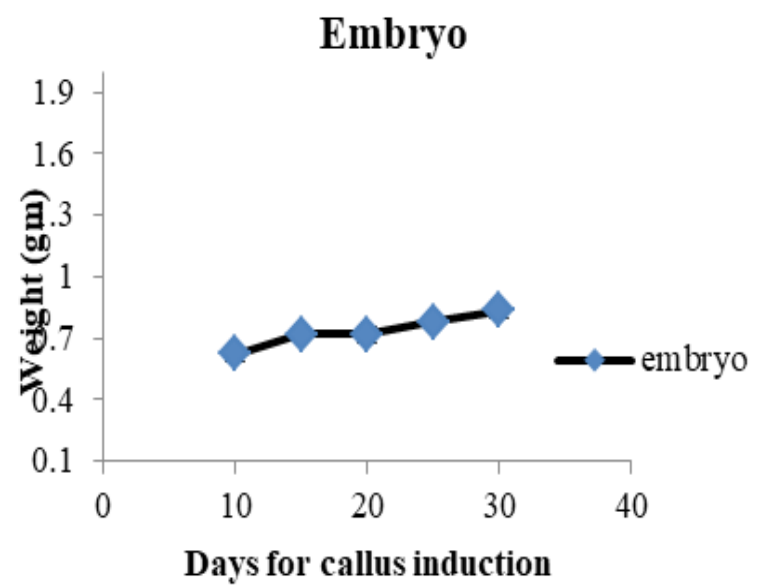

(b)

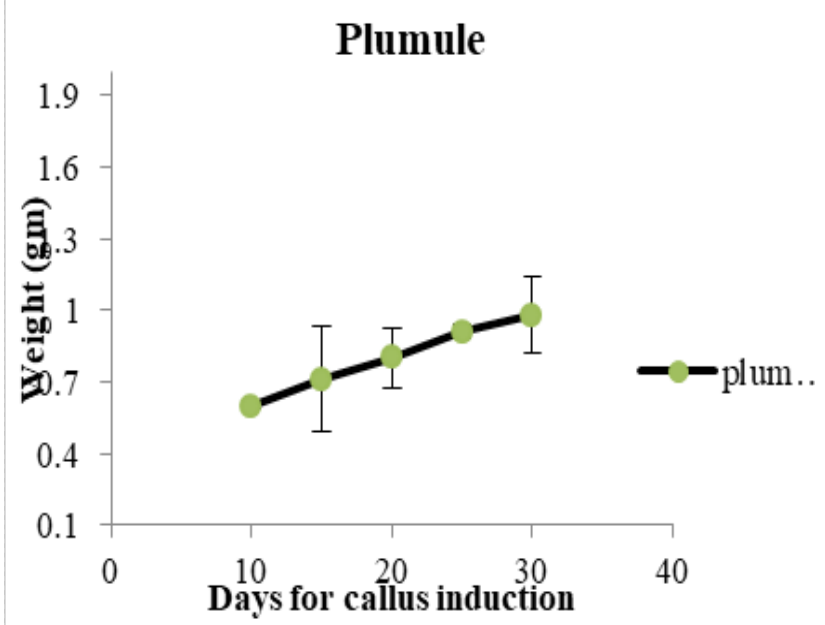

(d)

Fig. 4. Callus induced from four different explants: (a) radicle, (b) embryo, (c) cotyledon, (d) plumule, showing variation in weight with respect to the time. Statistically significant at 0.05 level of significance. Error bar indicates the standard deviation. 


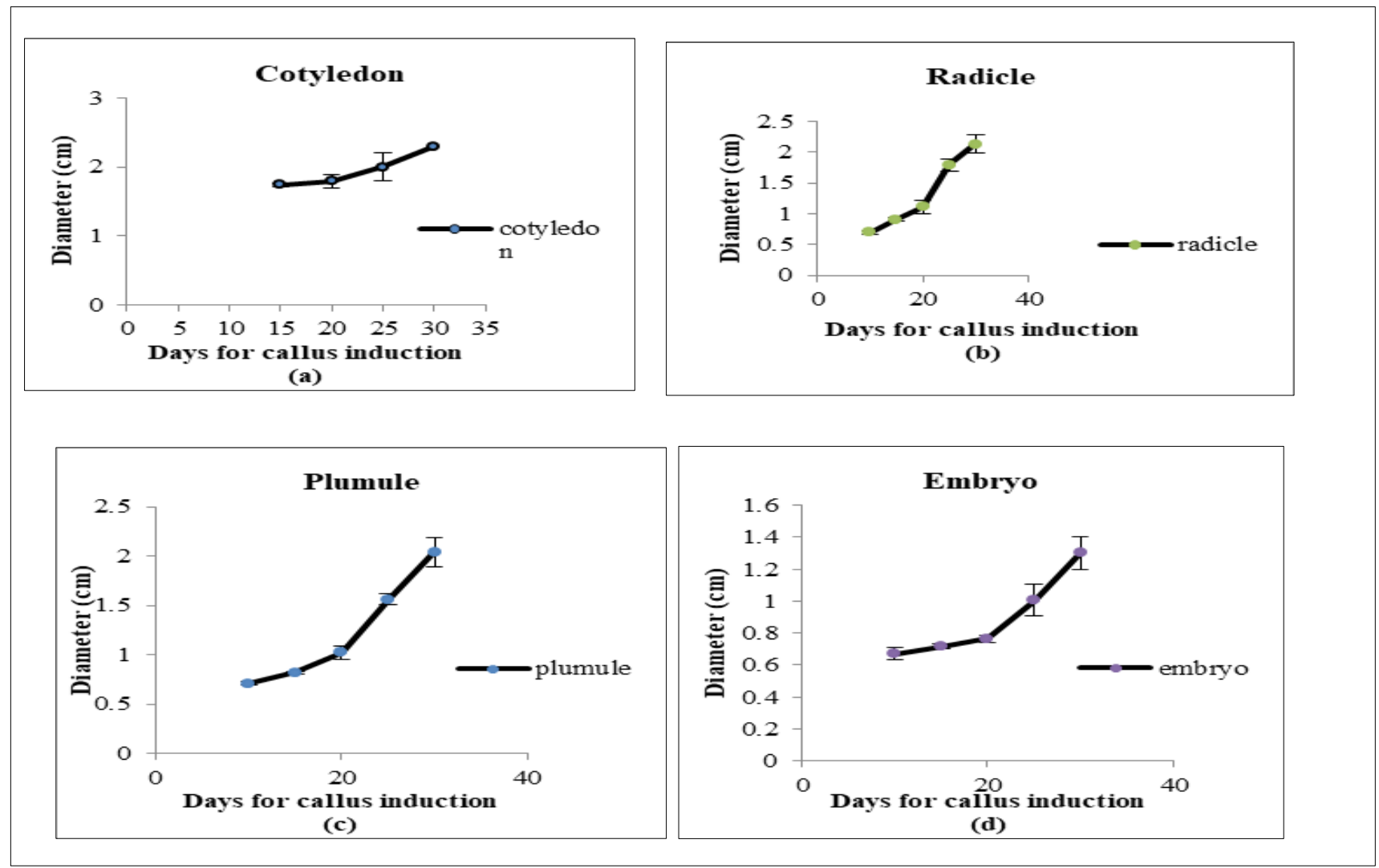

Fig. 5. Callus induced from four different explants: (a) cotyledon, (b) radicle, (c) plumule, (d) embryo: showing variation in diameter with respect to the time. Statistically significant at 0.05 level of significance. Error bar indicates the standard deviation.
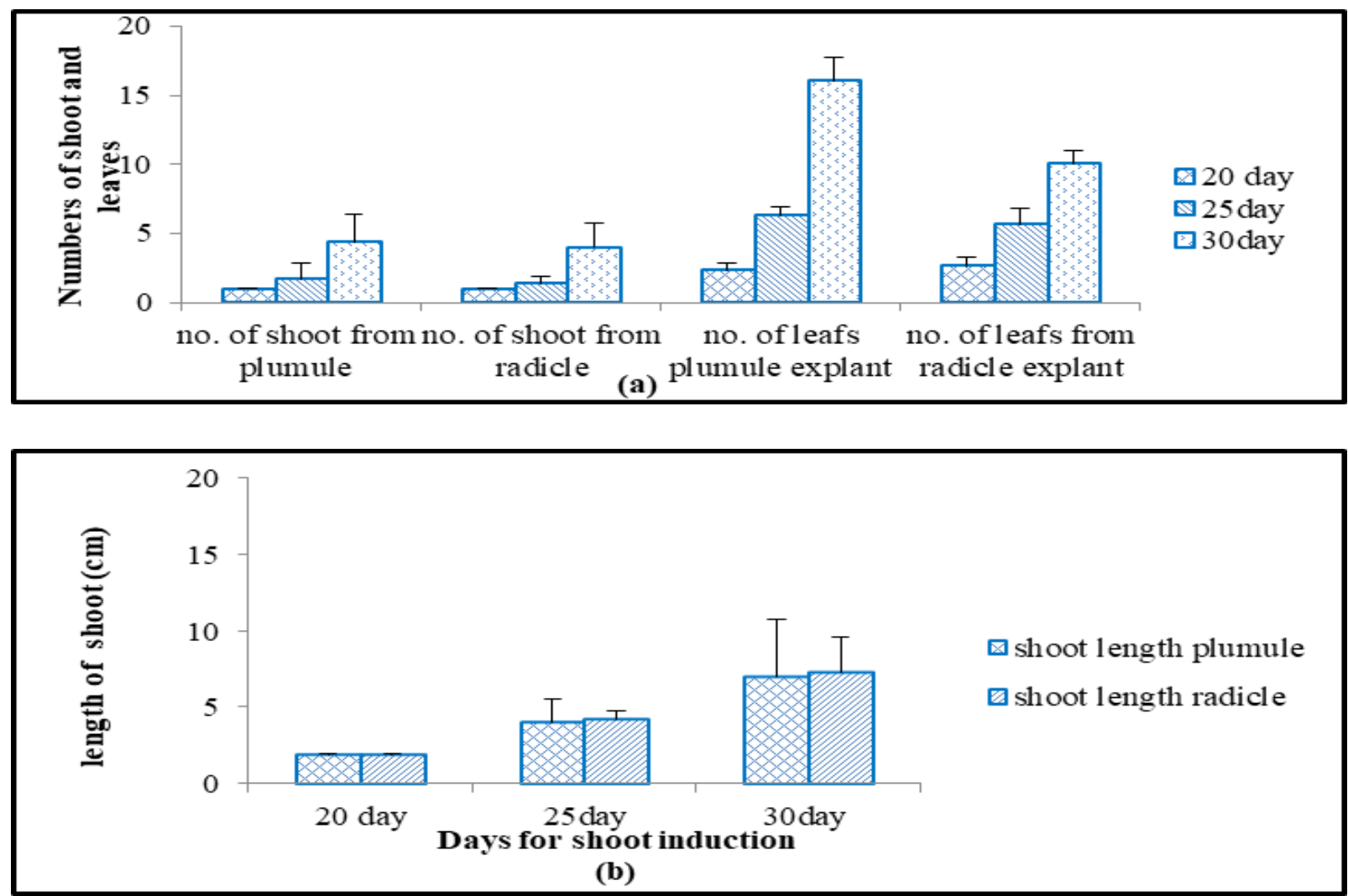

Fig. 6. (a) Number of shoot and number of leaves from the regenerated callus from plumule and radicle explant respectively. Error bar indicates the standard deviation. (b) Measurement of shoot length from the regenerated callus from plumule and radicle explant. Error bar indicates the standard deviation, average sample size $16(n=4)$.

and $2.00 \mathrm{mg} / \mathrm{l}$ of NAA and (ii) $2.00 \mathrm{mg} / \mathrm{l}$ of BAP, $(2.00$ $\mathrm{mg} / \mathrm{l})$ of NAA. These results clearly tell us that a higher concentration of BAP and 2, 4-D promotes multiple shoot induction and shoot growth. It also promotes growth in terms of number of leaves, nodes and shoots. This is due to an increase in the plasticity 


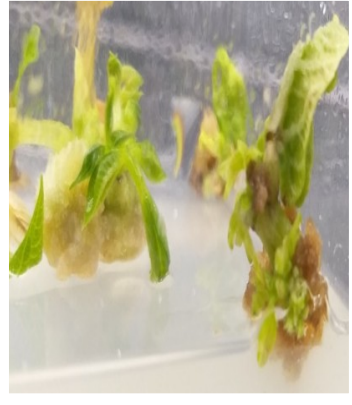

(a)

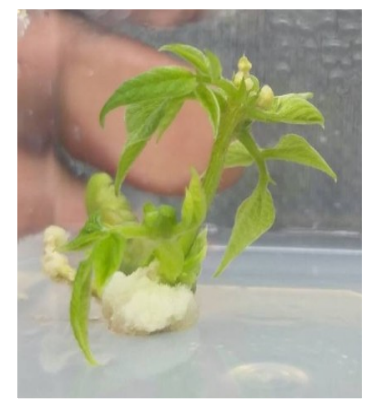

(b)
Fig. 7. Multiple shoot induction from callus induced from (a) plumule and (b) radicle explants with $2.00 \mathrm{mg} / \mathrm{l}$ of BAP and $0.25 \mathrm{mg} / \mathrm{l}$ of 2, 4-D after 30 days (Magnification 1x).

of the cell wall which helps in the movement of water in and out of the cell, resulting in cell elongation. The explants taken from seeds showed a higher frequency of shoot regeneration and multiple shoot induction per explant (13).

\section{Effect of PGRs on the growth of root}

The medium supplemented with PGRs help the regenerated callus in multiple root induction, varying in number and size. It has been observed that higher concentration of auxin induces the root to come out rapidly and also helps in the increases of the root length. This may be due to a change in the cellular organization of callus. Some callus also gave rise to only root induction and has grown up to $25 \mathrm{~cm}$ long. This result suggests that the optimum concentration of PGRs is very important for callus induction and multiple shoot induction. Shoot induction medium $2.00 \mathrm{mg} / \mathrm{l}$ of BAP, $0.25 \mathrm{mg} / \mathrm{l}$ of 2, 4-D with addition of NAA $(2.00 \mathrm{mg} / \mathrm{l})$ was found to be very effective in rooting. The minimum number of days for rooting is 21 days. After root induction, the regenerated plants were transferred into soilrite (nutrient medium). The removal of agar medium from induced root improved hardening process and also lowers the chances of infection. Rooting condition was also maintained at $27 \pm 2{ }^{\circ} \mathrm{C}$ temperature, $84 \pm 5 \%$ humidity, 280-400 $\mu \mathrm{mol} \mathrm{m} \mathrm{m}^{-2}$ light intensity and $13 \mathrm{hr}$ light/11 hr dark photoperiod. Finally, the plantlets were kept in controlled environment in green house. The rate of survival of regenerated plant was $\sim 10 \%$.

\section{Discussion}

P. vulgaris $\mathrm{L}$. is a vital crop and known for its nutritional content. The production of $P$. vulgaris is deeply affected due to different biotic and abiotic stresses. So it is very important to produce $P$. vulgaris through plant tissue culture, which can be used for quick multiplication and for biotechnological studies. The selection of explants is crucial for any plant tissue culture experiment. For explant selection, immature tissue materials are ideal $(18,19)$ like young leaves, embryo, cotyledon, nodes, root tip, stem etc. Mature explant tissues contain old cells and more cellular contents like carbohydrate, lipid, proteins and metabolite chemicals and hence are not suitable as explants. The higher cellular content is stumbling block for explant to give rise to callus because it releases its cellular content in media leading to necrosis of explant.

For this study, 6 explants of immature tissue materials were taken at the beginning namely root tip, leaf, cotyledon, embryo, radicle and plumule. The selected explants were dissected $(3.3 \mathrm{~mm})$ in size aseptically and surface sterilized. The sterilization of explants is very critical for any tissue culture experiments. This allows us to remove all the septic agents present in the explant like, fungal spore, dust, bacterial agent etc which causes contamination of growth medium and necrosis of explant (20). Therefore, this step is important to increase the chances of getting more number of calluses with a minimum risk of contamination. All these explants were transferred into the MS medium supplemented with essential micro and macronutrients, amino acids, carbon source and solidifying agent $(0.8 \%$ agar). The medium was also provided with different concentrations of plant growth regulator cytokinin and auxin.

Out of 6 explants, 4 explants from cotyledon, embryo, plumule and radicle showed positive response to MS media supplemented with PGRs when kept under incubation in optimum condition at $25 \pm 2$ ${ }^{\circ} \mathrm{C}$ for one week in dark, followed by $16 \mathrm{hr}$ light/ $8 \mathrm{hr}$ dark photoperiod of $45 \mu \mathrm{mol} \mathrm{m} \mathrm{m}^{-2} \mathrm{~s}^{-1}$. Leaf and root tip didn't show any changes to PGRs combinations. Wounding is an important factor to produce callus form any part of the plant. In trees, wounding causes callus formation (21) and accumulation of phytoalexins and pathogen-related protein is often seen in the callus formed by wounding (22). This is the method to prevent infection and water deficiency. Callus derived from wound involves different cell types including pith cells, cortical cells and vascular cells. In favorable condition, this calli also regenerate into a new organ, tissue or plant indicating that the calluses obtained through wounding are highly pluripotent (21). It was also found that wounding promotes callus induction in Arabidopsis seedlings (23). Similarly in this study, callus induction first started at the cut region and slowly covered the entire explant in all the 4 explants, confirming that wounding triggers callus induction guided by the upregulation of cytokinin signaling (23). This is due to the expression of the WIND gene after the explant encounters different hormonal concentrations of cytokinin and auxin. Callus induction involves complex pathways regulated by auxin and cytokinin. Auxin-induced callus formation involves auxin signaling, which is regulated by ARFs (auxin response transcription factors). Specifically, ARF7 and ARF19 regulate the activity of LBD (lateral organ boundaries domain) family transcriptional factors LBD16, LBD17, LBD18 and LBD29 (5). LBD controls the regulation of E2Fa (E2 promoter binding factor a), which plays an important role in cell cycle re-entry, thereby promoting cell proliferation (24).

Cytokinin-induced callus formation is regulated by cytokinin signaling regulatory pathways. Cytokinin activates APETALA2/ETHYLENE RESPONSIVE FACTOR (AP2/ERF), which is responsible for the activation of another family of transcription 
factor namely enhanced shoot regeneration (ESR). Together ESR1 and ESR2 regulate cell cycle and induce the expression of CYCD1;1, CYCD3;3 and other cell cycle regulators. The activation of these genes take place when the explant encounters the different concentrations of auxin and cytokinin resulting in callus formation (6).

Higher concentration of auxin and cytokinin (2.00 mg/l BAP, 1.00 mg/l 2,4-D 0.20 mg/l NAA) doesn't have any effect in all the four selected explants. The other three hormonal concentrations showed a positive result for callus induction in the MS medium (Table 1). In general, callus show a wide range of texture in cellular masses from hard, compact, nodular to friable soft type. Colour varies from greenish, creamish or whitish around the callus or in a part of it due to chloroplast development. The callus obtained from the four explants has also shown differential behavior in terms of pattern and texture. Fibrous and yellowish (1.50 mg/l of BAP, $0.50 \mathrm{mg} / \mathrm{l}$ of 2,4-D, $0.10 \mathrm{mg} / \mathrm{l}$ of NAA), hard and dark brown (1.00 $\mathrm{mg} / \mathrm{l}$ of BAP, $0.25 \mathrm{mg} / \mathrm{l}$ of 2,4-D, $0.05 \mathrm{mg} / \mathrm{l}$ of NAA), compact and brownish $(0.50 \mathrm{mg} / \mathrm{l}$ of BAP, $0.125 \mathrm{mg} / \mathrm{l}$ of 2,4-D, $0.0025 \mathrm{mg} / \mathrm{l}$ of NAA), in case of plumule and radicle. However, callus obtained from embryo and cotyledon were found to be hard and dark brown $(1.50 \mathrm{mg} / \mathrm{l}$ of BAP, $0.50 \mathrm{mg} / \mathrm{l}$ of $2,4-\mathrm{D}, 0.10 \mathrm{mg} / \mathrm{l}$ of NAA), compact and brownish in embryo and hard and dark brown in cotyledon $(1.00 \mathrm{mg} / \mathrm{l}$ of BAP, 0.25 $\mathrm{mg} / \mathrm{l}$ of $2,4-\mathrm{D}, 0.05 \mathrm{mg} / \mathrm{l}$ of NAA). At $0.50 \mathrm{mg} / \mathrm{l}$ of BAP, $0.125 \mathrm{mg} / \mathrm{l}$ of $2,4-\mathrm{D}, 0.0025 \mathrm{mg} / \mathrm{l}$ of NAA cotyledon explant gave rise to compact and brownish calli. This is due to the presence of different types of cells in the 4 explants. Plumule and radicle which are a part of an embryo have a great potential to divide because they can develop into a plant when it is intact within cotyledon in the form of an embryo. Whereas cotyledon and complete embryo are not so responsive to differentiate into a regenerative callus. The problem with the cotyledon is the presence of nutritional content. When transferred to MS medium, cotyledon doesn't respond well compare to plumule and radicle. On the other hand, embryo mostly differentiates into a complete plant instead of callus (organogenesis). This suggests that for callus development, out of all the 6 explants, plumule and radicle are the most responsive explant in $P$. vulgaris.

The histological study revealed the obtained callus has arisen from hypertrophied parenchyma cell division (25). The calluses were fibrous in nature due to the presence of loosely arranged, vacuolated and elongated inner cells (26). The cells present towards the edge of the callus were closely arranged, isodiametric and cytoplasmically dense in nature (Fig. 2). The compact appearance of cells in callus is due to the presence of starch granules (Fig. 2). The outer cells in the callus underwent cell division results in a meristematic zone (25). These meristematic zones were consisting of enlarged nuclei and densely cytoplasmic isodiametric cells. Such cells were responded to specific hormonal signals, triggers dedifferentiation of parenchyma cells led to organ formation. The presence of such calli in shoot induction medium led to multiple shoot induction (25). The histological study gives confidence in the selection of callus for multiple shoot induction. Yellowish callus obtained from plumule and radicle explants were used for shoot induction. Callus obtained from cotyledon and embryo degrades, releasing phenolic contents resulting in necrosis of callus. The presence of auxin (2, 4-D and NAA) and cytokinin (BAP) is the key factor for multiple shoot induction from callus.

\section{Conclusion}

In the present study we found that BAP $(2.00 \mathrm{mg} / \mathrm{l})$ and 2, 4-D (0.25 mg/l) (growth condition $16 \mathrm{hr}$ light/8 $\mathrm{hr}$ dark photoperiod of $45 \mu \mathrm{mol} \mathrm{m} \mathrm{m}^{-2} \mathrm{~s}^{-1}$ ) contributes significantly to induce multiple shoots from callus developed from plumule and radicle explants followed by root induction at NAA $(2.00 \mathrm{mg} / \mathrm{l})$ concentration. However, shoot regeneration capability in $P$. vulgaris $L$. is less due to its recalcitrance nature. Information obtained from all the findings in the present study will help the reader regarding the selection of explant, optimum PGRs concentration and the use callus for multiple shoot regeneration in $P$. vulgaris. This knowledge will have great importance in the study of different developmental stages of callus in $P$. vulgaris and will be useful in developing a standard protocol for plant regeneration from explants, which can be used to create transgenic lines in $P$. vulgaris.

\section{Acknowledgements}

$\mathrm{AB}$ is thankful to university grant commission (UGC) and Maulana Azad National Fellowship (MANF) for financial assistance. $\mathrm{AB}$ is also thankful to Department of Biotechnology, Visva-Bharati, Santiniketan, India for infrastructural facilities.

\section{Authors' contributions}

$\mathrm{AB}$ and JB designed the experiments. $\mathrm{AB}$ carried out the experiments and analyzed. Both participated in manuscript preparation.

\section{Conflict of interests}

There is no conflict of interest declared by the authors.

\section{Supplementary files}

Fig. S1: Schematic representation of steps involve in callus induction and plant regeneration from explants.

\section{References}

1. Thorpe TA. History of plant tissue culture. Molecular Biotechnol. $\quad 2007 \quad$ Oct $1 ; 37(2): 169-80$ https://doi.org/10.1007/s12033-007-0031-3

2. Thorpe T. History of plant tissue culture. In Plant Cell Culture Protocols 2012 (pp. 9-27). Humana Press, Totowa, NJ https://doi.org/10.1007/978-1-61779-818-4_2

3. Pipan B, Meglič V. Diversification and genetic structure of the western-to-eastern progression of European Phaseolus vulgaris 
L. germplasm. BMC Plant Biol. 2019;19:1-6. https://doi.org/10.1186/s12870-019-2051-0.

4. Li SB, Xie ZZ, Hu CG, Zhang JZ. A review of auxin response factors (ARFs) in plants. Front Plant Sci. 2016;7:47. https://doi.org/10.3389/fpls.2016.00047

5. Fan $\mathrm{M}, \mathrm{Xu} \mathrm{C}, \mathrm{Xu} \mathrm{K}, \mathrm{Hu} \mathrm{Y}$. Lateral organ boundaries domain transcription factors direct callus formation in Arabidopsis regeneration. Cell Res. 2012;22:1169-80. https://doi.org/10.1038/cr.2012.63

6. Ikeuchi M, Sugimoto K, Iwase A. Plant callus: mechanisms of induction and repression. The Plant Cell. 2013;25:3159-73. https://doi.org/10.1105/tpc.113.116053.

7. Mastuti R, Munawarti A, Firdiana ER. The combination effect of auxin and cytokinin on in vitro callus formation of Physalis angulata L. A medicinal plant. InAIP Conference Proceedings 2017 Nov 29 (Vol. 1908, No. 1, p. 040007). AIP Publishing LLC. https://doi.org/10.1063/1.5012721

8. Neibaur I, Gallo M, Altpeter F. The effect of auxin type and cytokinin concentration on callus induction and plant regeneration frequency from immature inflorescence segments of seashore paspalum (Paspalum vaginatum Swartz). In Vitro Cell Dev Biol. 2008;44:480-86. https://doi.org/10.1007/s11627-008-9143-0

9. Su YH, Liu YB, Zhang XS. Auxin-cytokinin interaction regulates meristem development. Mol Plant. 2011;4:616-25. https://doi.org/10.1093/mp/ssr007

10. Ružić DV, Vujović TI. The effects of cytokinin types and their concentration on in vitro multiplication of sweet cherry cv. Lapins (Prunus avium L.). Horti Sci. 2008;35:12-21.

11. Wang W, Zhao X, Zhuang G, Wang S, Chen F. Simple hormonal regulation of somatic embryogenesis and/or shoot organogenesis in caryopsis cultures of Pogonatherum paniceum (Poaceae). Plant cell, Tissue and Organ Cult. 2008;95:57-67. https://doi.org/10.1007/s11240-008-9414-9

12. Bhatia S, Sharma K, Dahiya R, Bera T. Modern applications of plant biotechnology in pharmaceutical sciences. Academic Press; 2015 Jul 22. https://doi.org/10.1016/C2014-0-02123-5

13. Collado R, Bermúdez-Caraballoso I, García LR, Veitía N, Torres D, Romero C, Martirena- Ramírez A, Angenon G. Agrobacterium-mediated transformation of Phaseolus vulgaris L. using indirect organogenesis. Sci Hortic. 2015;195:89-100. https://doi.org/10.1016/j.scienta.2015.06.046

14. Hnatuszko-Konka K, Kowalczyk T, Gerszberg A, WiktorekSmagur A, Kononowicz AK. Phaseolus vulgaris Recalcitrant potential. Biotechnol Adv. 2014;32:1205-15. https://doi.org/10.1016/j.biotechadv.2014.06.001

15. Benderradji L, Brini F, Kellou K, Ykhlef N, Djekoun A, Masmoudi K, Bouzerzour H. Callus induction, proliferation and plantlets regeneration of two bread wheat (Triticum aestivum L.) genotypes under saline and heat stress conditions. ISRN Agron. 2012;2012:8. https://doi.org/10.5402/2012/367851

16. Murashige T, Skoog F. A revised medium for rapid growth and bio assays with tobacco tissue cultures. Physiol Plant. 1962;15:473-97. 3054.1962.tb08052.x

https://doi.org/10.1111/j.1399-

17. Kumlay AM, Ercisli S. Callus induction, shoot proliferation and root regeneration of potato (Solanum tuberosum L.) stem node and leaf explants under long-day conditions. Biotechnol Biotechnol Equip. 2015;29:1075-84 https://doi.org/10.1080/13102818.2015.1077685
18. Goldstein CS, Kronstad WE. Tissue culture and plant regeneration from immature embryo explants of barley, Hordeum vulgare. Theor Appl Genet. 1986;71:631-36. https://doi.org/10.1007/BF00264267

19. Holme IB, Petersen KK. Callus induction and plant regeneration from different explant types of Miscanthus $x$ Ogiformis Honda 'Giganteus'. Plant Cell, Tissue and Organ Cult. 1996;45:43-52. https://doi.org/10.1007/BF00043427

20. Cassells AC. Contamination and its impact in tissue culture. In: IV International Symposium on In Vitro Culture and Horticultural Breeding 5602000 Jul 2. Pp. 353-59. https://doi.org/10.17660/ActaHortic.2001.560.66

21. Stobbe H, Schmitt U, Eckstein D, Dujesiefken D. Developmental stages and fine structure of surface callus formed after debarking of living lime trees (Tilia sp.). Ann Bot. 2002;89:77382. https://doi.org/10.1093/aob/mcf137

22. Bostock RM, Stermer BA. Perspectives on wound healing in resistance to pathogens. Annu Rev Phytopathol. 1989;27:34371. https://doi.org/10.1146/annurev.py.27.090189.002015

23. Iwase A, Mitsuda N, Koyama T, Hiratsu K, Kojima M, Arai T, Inoue Y, Seki M, Sakakibara H, Sugimoto K, Ohme-Takagi M. The AP2/ERF transcription factor WIND1 controls cell dedifferentiation in Arabidopsis. Curr Biol. 2011;21:508-14 https://doi.org/10.1016/j.cub.2011.02.020

24. De Veylder L, Beeckman T, Beemster GT, de Almeida Engler J, Ormenese S, Maes S, Naudts M, Van Der Schueren E, Jacqmard A, Engler G, Inzé D. Control of proliferation, endoreduplication and differentiation by the Arabidopsis E2Fa-DPa transcription $\begin{array}{lll}\text { factor. The EMBO J. 2002;21:1360-38. } & \end{array}$ https://doi.org/10.1093/emboj/21.6.1360

25. Mello MO, Melo M, Appezzato-da-Glória B. Histological analysis of the callogenesis and organogenesis from root segments of Curcuma zedoaria Roscoe. Braz Arch Biol Technol. 2001;44:197-203. 89132001000200014 https://doi.org/10.1590/S1516-

26. Laublin G, Saini HS, Cappadocia M. In vitro plant regeneration via somatic embryogenesis from root culture of some rhizomatous irises. Plant Cell Tissue and Organ Cult. 1991;27:15-21. https://doi.org/10.1007/BF00048200

\section{Additional information}

Peer review information: Plant Science Today thanks Sectional Editor and the other anonymous reviewers for their contribution to the peer review of this work.

Reprints and permissions information is available at https://horizonepublishing.com/journals/index.php/PST/open_access_policy

Publisher's Note: Horizon e-Publishing Group remains neutral with regard to jurisdictional claims in published maps and institutional affiliations.

To cite this article: Besra A, Basak J. Efficient regeneration protocol for callus and shoot induction from recalcitrant Phaseolus vulgaris L. explants under optimum growth conditions. Plant Science Today. 2021;8(4):786-794. https://doi.org/10.14719/pst.2021.8.4.1205

Plant Science Today, published by Horizon e-Publishing Group, is covered by Scopus, Web of Science, BIOSIS Previews, Clarivate Analytics, etc. See https://horizonepublishing.com/journals/index.php/PST/indexing_abstracting 